DOI: https://dx.doi.org/ 10.33289/IJRPC.10.1.2020.10(3)

\title{
FORMULATION AND EVALUATION OF HERBAL COUGH SYRUP FROM SEEDS EXTRACT OF HEDGE MUSTARD
}

\author{
Vikash Sharma ${ }^{1}$, Saurabh Singh ${ }^{1}$, Arushi Dixit ${ }^{2}$ and Alka Saxena ${ }^{2 *}$ \\ ${ }^{1}$ G.C.R.G. Memorial Trust's Group of Institutions, \\ Faculty of Engineering, Lucknow, Uttar Pradesh, India. \\ ${ }^{2}$ R\&D Deapartment, Acube Life Sciences, \\ Lucknow, Uttar Pradesh, India.
}

\begin{abstract}
In recent years there is a spurt in the interest regarding survival of Ayurvedic forms of medication. In the global perspective, there is a shift towards the use of medicine of herbal origin, as the dangers and the shortcoming of modern medicine have started getting more apparent, majority of Ayurvedic formulation are prepared from herbs. Syrup is very popular dosage form of cough and cold medications, ease of patient compliance. The objective of this study is to develop a herbal cough syrup and to check the anti bacterial activity of the extract of seeds of Hedge mustard used for the formulation of herbal cough syrup against different bacteria (Staphylococcus aureus, E.coli, Salmonella sp., Pseudomonas aeruginosa, B.subtilis), and to evaluate the physicochemical parameter of cough syrup as well. The cough syrup formulated with simple syrup $66.67 \% \mathrm{w} / \mathrm{v}$ as sugar base. Quality of final herbal syrup was evaluated with different parameters: physical appearance (colour, odour, taste), $\mathrm{pH}$ and turbidity. The formulated syrup under gone stability studies and microbial test for 72 hours, no turbidity was observed and no microbial growth was seen.
\end{abstract}

Keywords: Hedge mustard, Herbal cough syrup, Antibacterial activity, Sisymbrium officinale.

\section{INTRODUCTION}

Sisymbrium officinale (L.) Scop., synonym Erysimum officinale, commonly known as hedge mustard in English, erísimo in Spanish, erisimo or erba cornacchia in Italian, and velar in French, is a medicinal plant that belongs to the Brassicaceae family. This species could have potential for introduction into the leafy vegetable production for the minimally processed or fresh-cut industry. S. officinale is a terophyte scapose plant with a reddish-violet erect trunk, that present a lot of trichomes and many branches. Basal leaves are different from the upper ones with a dentate shape. Hedge mustard has a linear racemose inflorescence; each flower has four small (1-2 $\mathrm{mm}$ ) yellow petals; the fruit is a tiny siliqua, close-fitting to the trunk. Flowering occurs in Spring-Summer, from May to July-August, depending on the climate. Siliqua pods usually are pubescent, once they reach maturity they release seeds. Seeds are very small, each siliqua can contain from 10 to 20 seeds. S. officinale is endemic in the Eurasian continent and widespread in all Italian regions from 0 to $1000 \mathrm{~m}$. above sea level, and rarely up to 2400 $\mathrm{m}$ above sea level. ${ }^{1}$

S. officinale is largely known as "singer's plant" and is used among singers, actors, and professionals who use the voice for working. The therapeutic activity of this plant is attributed to its sulfurated components. Dried flowering aerial parts contain: total glucosinolates $(0.63-0.94 \%)$, mucilage (13.5$10.9 \%)$, total thiols $(8.9-10.2 \%)$, and total flavonoids $(0.50-0.56 \%)$. The main glucosinolate in $\mathrm{S}$. officinale is glucoputranjivine. ${ }^{2}$ historically, the sulphated compounds are reputed to stimulate the mucosal secretion in the upper respiratory 
tract, so increasing expectoration. It is used mainly against the inflammations and catarrhs of the larynx, especially to combat hoarseness, as well as against cough, pulmonary catarrh, etc., and scurvy too. The fresh plant is preferably used. The pharmacological activity of Sisymbrium shows anti-inflammatory, analgesic, antitussive, myorelaxant and broad spectrum antimicrobial properties. ${ }^{3}$

It has also been found that the seeds contain small quantities of cardenolides. It is good for all diseases of the chest and lungs, hoarseness of voice. The juice made into a syrup with honey or sugar, is no less effectual for all other coughs, wheezing and shortness of breath, the seed is held to be a special remedy against poison and venom. It was formerly used for hoarseness, weak lungs and to help the voice. Herbalists use the juice and flowers for bronchitis and stomach ailments, among other uses, and as a revitalizer. In Tibetan medicine it is used to repress the symptoms of food poisoning.

In recent years, plant derived products are increasingly being sought out as medicinal products, nutraceuticals and cosmetics and are available in health food shops and pharmacies over the counter as selfmedication or also as drugs prescribed in the non-allopathic systems. Herbal medicines widely used in health-care in both developed and developing countries are complex chemical mixtures prepared from plants and are limited in their effectiveness because they are poorly absorbed when taken orally. Cough Syrup is liquid dosage form; the oral use of liquid pharmaceutical has generally been justified on the basis of ease of administration to those individuals who have difficulties in swallowing solid dosage forms. Syrup is a concentrated mixture of sugar and purified water. The high sugar content distinguishes syrups from other types of solutions. Syrups may or may not contain medication or added flavouring agents. Syrups without a medication, but with a flavouring agent, are called non-medicated or flavoured syrups. Flavoured syrups are often used as vehicles for unpleasant tasting medications: the result is medicated syrup. The high amount of sugar present in syrups predisposes them to bacterial contamination, so they often contain a preservative. ${ }^{4}$ According to an estimate of the World Health Organization (WHO); about $80 \%$ of the world population still uses herbs and other traditional medicines for their primary health care needs. Herbal formulations have reached widespread acceptability as therapeutic agents for diabetics, arthritics, liver diseases, cough remedies, memory enhancers and adoptogens. ${ }^{5}$ As per WHO definition, there are three kinds of herbal medicines: raw plant material, processed plant material and medicinal herbal products. Herbal drugs are finished labelled products that contain active ingredients such as aerial or underground parts of plant or other plant material or combination thereof, whether in the crude state or as plant preparations. ${ }^{6}$

\section{MATERIAL AND METHODS \\ Plant material}

The seeds of Hedge mustard were collected from local market of Lucknow. It was authenticated by Acube Lifesciences, Lucknow.

\section{Method of preparation of extract}

The seeds were cleaned, shade dried and powdered mechanically and stored in air tight containers. The extraction was carried out by maceration. About $5 \mathrm{gm}$ of powder was extracted with $80 \%$ methanol. The extract was kept for 48 - 72 hours and after that it was filtered. The extract was preserved in refrigerator at $4^{\circ} \mathrm{C}$.

\section{Antimicrobial activity}

In vitro antibacterial activity of the methanolic extract was studied against gram +ve and -ve bacterial strains by the agar well diffusion method. Nutrient Agar was used as the bacteriological medium. The Nutrient agar media was melted and cooled to $48-50 \stackrel{\circ}{C}$ was then poured into sterile petridishes to give a solid plate. Wells were prepared in the seeded agar plates. The test compound $(50 \mu \mathrm{l}, 75 \mu \mathrm{l}$ and $100 \mu \mathrm{l}$ ) was introduced in the well. The plates were incubated overnight at $37^{\circ} \mathrm{C}$. The antimicrobial spectrum of the extract was determined for the bacterial species in terms of zone sizes around each well. The diameters of zone of inhibition produced by the agent were compared with those produced by the commercial control antibiotic ciprofloxacin.

\section{Phytochemical screening}

Qualitative phytochemical analysis for secondary metabolites was carried out for the crude extracts as per standard methods.

\section{a) Saponin}

$5 \mathrm{ml}$ distilled water was added to $1 \mathrm{ml}$ plant extract and then shaken well, froth formation took place. Stability of froth confirms the presence of saponin in plant extract.

\section{b) Tannin}

$1 \mathrm{ml} 5 \% \mathrm{FeCl}_{3}$ was added to $1 \mathrm{ml}$ plant extract. Appearance of dark blue, black or dark green confirms presence of tannin in plant extract. 


\section{c) Flavonoid}

$2 \mathrm{ml} 1 \% \mathrm{NaOH}$ was added to $1 \mathrm{ml}$ plant extract, presence of yellow colour indicates the in plant extract.

\section{d) Carbohydrate}

$1 \mathrm{ml}$ Fehling $A$ and $1 \mathrm{ml}$ Fehling $B$ was added to $2 \mathrm{ml}$ plant extract and then test tube was heated in water bath for $20 \mathrm{~min}$. Appearance of red precipitate confirms the presence of carbohydrate in plant extract.

\section{e) Protein}

$1 \mathrm{ml}$ of $1 \% \mathrm{CuSO}_{4}$ and $1 \mathrm{ml}$ of $1 \% \mathrm{NaOH}$ was added to $2 \mathrm{ml}$ plant extract. Appearance of purple color confirms the presence of protein in plant extract.

\section{f) Alkaloid}

$1 \mathrm{ml}$ iodine was added to $1 \mathrm{ml}$ plant extract. Appearance of reddish brown precipitate confirms the presence of alkaloid in plant extract.

\section{g) Starch}

$1 \mathrm{ml}$ iodine was added to $1 \mathrm{ml}$ plant extract. Appearance of blue or black color confirms the presence of starch in plant extract.

\section{h) Fat Test}

$1 \mathrm{~mL}$ of distilled water and few drops of ethanol were added to $1 \mathrm{~mL}$ of plant extract.

The white color precipitate formed showed the presence of fat in the plant extract.

\section{i) Terpenoid Test}

$250 \mu \mathrm{l}$ chloroform was added to $500 \mu \mathrm{l}$ plant extract then $625 \mu \mathrm{l}$ Conc. $\mathrm{H}_{2} \mathrm{SO}_{4}$ was added to the solution. Reddish brown ppt, of the solution confirms presence of terpenoids.

\section{Method of preparation of simple syrup (usp)}

$666.7 \mathrm{~g}$ of Sucrose was weighed and added to purified water and heated until it dissolved with occasional stirring. Sufficient boiling water was added to produce $1000 \mathrm{ml}^{7}$

\section{Method of preparation of final herbal syrup}

One part of decoction was mixed with five parts of simple syrup (1:5), peppermint oil $(0.02 \%)$ and required quantity of Sodium benzoate $(0.2 \%)$ was added to the above mixture (Sodium benzoate) act as a preservative to the above mixture. Solubility was checked by observing the clarity of solution visually. The final herbal syrup was then subjected for evaluation.

\section{Evaluation of herbal syrup \\ Physicochemical parameters}

The herbal syrup was evaluated for various physicochemical parameters such as physical appearance (colour, odour, taste), $\mathrm{pH}$.

\section{a) Color examination}

Five $\mathrm{ml}$ final syrup was taken into watch glasses and placed against white back ground inwhite tube light. It was observed for itscolor by naked eye.

\section{b) Odour examination}

Two $\mathrm{ml}$ of final syrup was smelled individually. The time interval among two smelling was kept 2 minutes to nullify the effect of previous smelling.

\section{c) Taste examination}

A pinch of final syrup was taken and examined for its taste on taste buds of the tongue.

\section{d) Determination of $\mathrm{pH}$}

Placed an accurately measured amount $10 \mathrm{ml}$ of the final syrup in a $100 \mathrm{ml}$ volumetric flask and made up the volume up to $100 \mathrm{ml}$ with distilled water. The solution was sonicated for about 10 minutes. $\mathrm{pH}$ was measured with the help of digital $\mathrm{pH}$ meter.

\section{Stability testing}

Stability testing of the prepared herbal syrup was performed on keeping the samples at accelerated temperature conditions. The final syrup was taken in culture tubes and were kept at accelerated temperature at $4^{\circ} \mathrm{C}$, Room temperature and $47^{\circ} \mathrm{C}$ respectively. The samples were tested for all the physicochemical parameters, turbidity and homogeneity at the interval of $24 \mathrm{hr}, 36 \mathrm{hr}$ and $72 \mathrm{hr}$ to observe any change.

\section{RESULTS AND DISCUSSION}

The basic objective of this work was to develop herbal cough syrup from seeds of Hedge mustard. It has also been found that the seeds contain small quantities of cardenolides. The development of such herbal syrup will mark an important advancement in the area of Coughs, Use as a gargle or mouthwash, Chronic bronchitis, Urinary tract diseases, Swelling (inflammation) of the gallbladder and Other conditions.

The present investigation examines development and evaluation of herbal syrup.

Phytochemical screening investigations on the phytochemical screening of Hedge mustard extracts revealed the presence of carbohydrates, alkaloids, tannin, saponin, fat, terpenoid and flavonoids, which are known to be biologically active. These metabolites can exert antimicrobial activity through different 
mechanisms. The antimicrobial activity of methanolic extract of hedge mustard seeds were tested against bacterial strains (Staphylococcus aureus, E.coli, Salmonella sp., Pseudomonas aeruginosa, B.subtilis), the extract showed zone of inhibition.

The formulated herbal syrup was found to be clear without particles and sweet in taste. The developed herbal syrup was evaluated for stability studies for 24,36 and 72 hours with varying temperature of $4^{\circ} \mathrm{C}$, room temperature and $47^{\circ} \mathrm{C}$. There was no change observed in physical appearance (colour, odour, taste), $\mathrm{pH}$ of the formulated syrup. It did not produce turbidity at lower temperature of $4^{\circ} \mathrm{C}$. It was clear homogenous liquid without turbidity at higher storage temperature of $47^{\circ} \mathrm{C}$ too. Thus it can be concluded that the herbal syrup was in suitable form which was developed.

\section{CONCLUSION}

In recent years there is a spurt in the interest regarding survival of Ayurvedic forms of medication. In the global perspective, there is a shift towards the use of medicine of herbal origin, as the dangers and the shortcoming of modern medicine have started getting more apparent, majority of Ayurvedic formulation are prepared from herbs. Syrup is very popular dosage form of cough and cold medications, ease of patient compliance.

Sisymbrium officinale, known as Hedge mustard, (formerly Erysimum officinale) is a plant in the family Brassicaceae. Hedge mustard contains an essential oil, rich in sweet-smelling sulphur compounds, consisting mainly of glucosinolates. It has also been found that the seeds contain small quantities of cardenolides.

The Phytochemical properties of the extract were evaluated. The methanolic extract showed the presence of various phytochemicals such as, Flavonoid, Alkaloid, Saponin, Protein, Carbohydrate, Starch, Fat, Terpenoid. The extract was tested for antimicrobial activity. Methanolic extract showed good activity at different concentration. The methanolic extract were formulated as a herbal cough syrup of one part of decoction was mixed with five parts of simple syrup (1:5), peppermint oil $(0.02 \%)$ and required quantity of Sodium benzoate $(0.2 \%)$ was added to the above mixture (Sodium benzoate) act as a preservative to the above mixture. Solubility was checked by observing the clarity of solution visually. The final herbal syrup was then subjected for evaluation.

\section{ACKNOWLEDGEMENT}

Authors are grateful to Acube Lifesciences, Lucknow for the support and providing facilities to carry out this work.

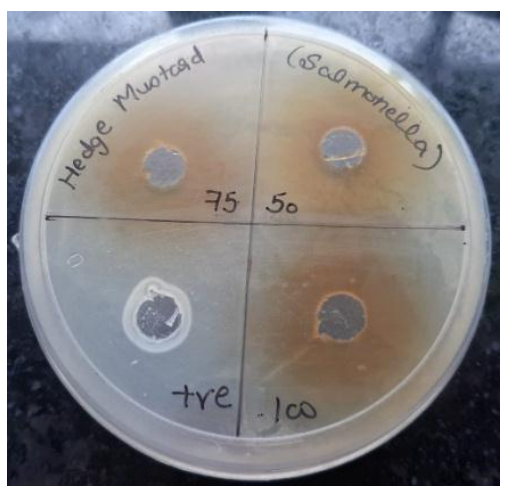

Fig. 1: MIC against Salmonella sp.

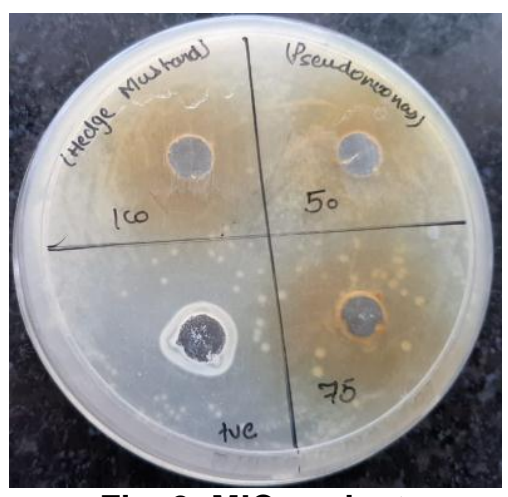

Fig. 2: MIC against Pseudomonas aeruginosa

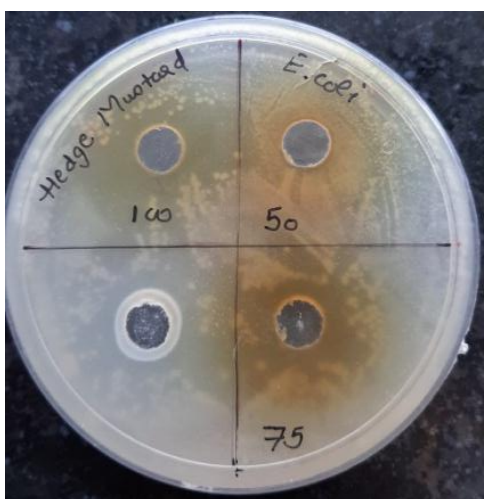

Fig. 3: MIC against E.Coli 

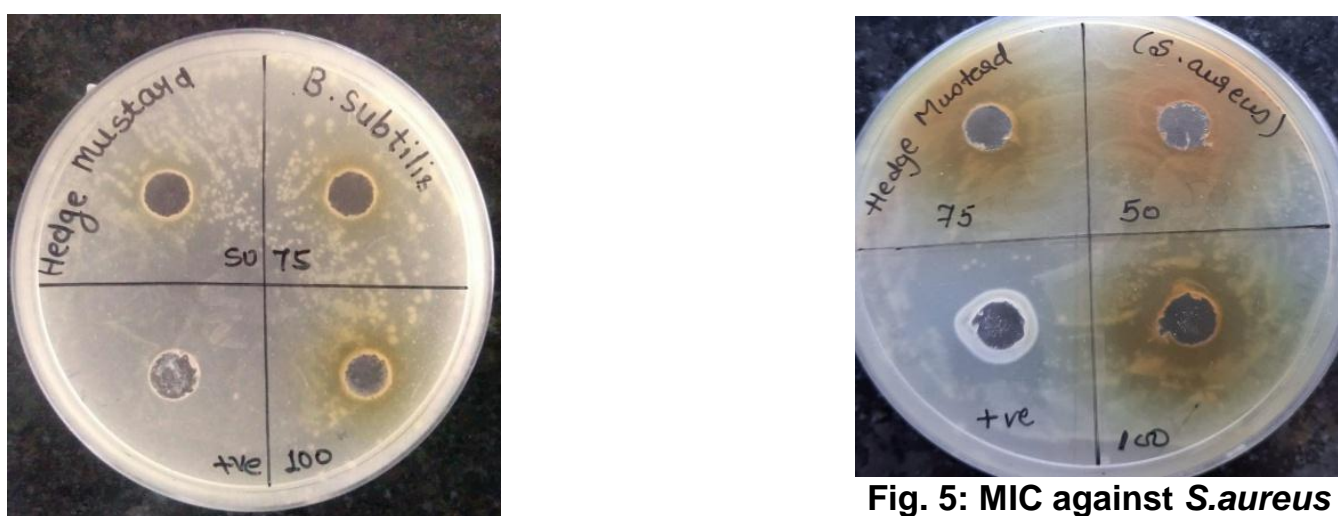

Fig. 4: MIC against B.subtilis

Fig. 5: MIC against S.aureus

Table 1: Result of Physicochemical parameters of developed herbal syrup

\begin{tabular}{|c|c|c|}
\hline Sr. No. & Parameter & Result \\
\hline 1 & Color & Yellow \\
\hline 2 & Odor & Sweet aromatic \\
\hline 3 & Taste & Sweet \\
\hline 4 & $\mathrm{pH}$ & 5.8 \\
\hline
\end{tabular}

Table 2: Stability studies through Physicochemical parameters of developed herbal Syrup.

\begin{tabular}{|c|c|c|c|c|c|c|}
\hline \multirow{2}{*}{$\begin{array}{c}\text { Time } \\
\text { Duration } \\
\text { (inhour) }\end{array}$} & Temperature $\left({ }^{\circ} \mathbf{C}\right)$ & \multicolumn{5}{|c|}{ Physicochemical parameters } \\
\cline { 2 - 7 } & & Color & Odor & Taste & pH & $\begin{array}{c}\text { Turbidity/ } \\
\text { Homogeneity }\end{array}$ \\
\hline \multirow{3}{*}{24} & $4^{\circ} \mathrm{C}$ & $\mathrm{NC}$ & $\mathrm{NC}$ & $\mathrm{NC}$ & 5.8 & No Turbidity \\
\cline { 2 - 7 } & $\mathrm{Room}$ temp & $\mathrm{NC}$ & $\mathrm{NC}$ & $\mathrm{NC}$ & 5.8 & $\mathrm{X}$ \\
\cline { 2 - 7 } & $47^{\circ} \mathrm{C}$ & $\mathrm{NC}$ & $\mathrm{NC}$ & $\mathrm{NC}$ & 5.8 & No Turbidity \\
\cline { 2 - 7 } & $4^{\circ} \mathrm{C}$ & $\mathrm{NC}$ & $\mathrm{NC}$ & $\mathrm{NC}$ & 5.8 & No Turbidity \\
\cline { 2 - 7 } & $\mathrm{Room}$ temp & $\mathrm{NC}$ & $\mathrm{NC}$ & $\mathrm{NC}$ & 5.8 & X \\
\cline { 2 - 7 } & $47^{\circ} \mathrm{C}$ & $\mathrm{NC}$ & $\mathrm{NC}$ & $\mathrm{NC}$ & 5.8 & No Turbidity \\
\cline { 2 - 7 } & $4^{\circ} \mathrm{C}$ & $\mathrm{NC}$ & $\mathrm{NC}$ & $\mathrm{NC}$ & 5.8 & No Turbidity \\
\cline { 2 - 7 } & $\mathrm{Room}$ temp & $\mathrm{NC}$ & $\mathrm{NC}$ & $\mathrm{NC}$ & 5.8 & X \\
\cline { 2 - 7 } & $47^{\circ} \mathrm{C}$ & $\mathrm{NC}$ & $\mathrm{NC}$ & $\mathrm{NC}$ & 5.8 & No Turbidity \\
\hline
\end{tabular}

NC = No Change, $X=$ Original condition

Table 3: The antimicrobial activity and MIC of the prepared extract

\begin{tabular}{|c|c|c|c|c|}
\hline \multirow{2}{*}{ Test Bacteria } & \multicolumn{4}{|c|}{ Zone of Inhibition (in mm) } \\
\cline { 2 - 5 } & $\mathbf{5 0} \boldsymbol{\mu l}$ & $\mathbf{7 5} \boldsymbol{\mu l}$ & $\mathbf{1 0 0} \boldsymbol{\mu l}$ & positive \\
\hline Staphylococcus aureus & 3 & 5 & 8 & 13 \\
\hline E.coli & 4 & 7 & 10 & 15 \\
\hline Salmonella sp. & 5 & 10 & 12 & 15 \\
\hline Pseudomonas aeruginosa & 5 & 7 & 11 & 17 \\
\hline B.subtilis & 2 & 4 & 7 & 20 \\
\hline
\end{tabular}




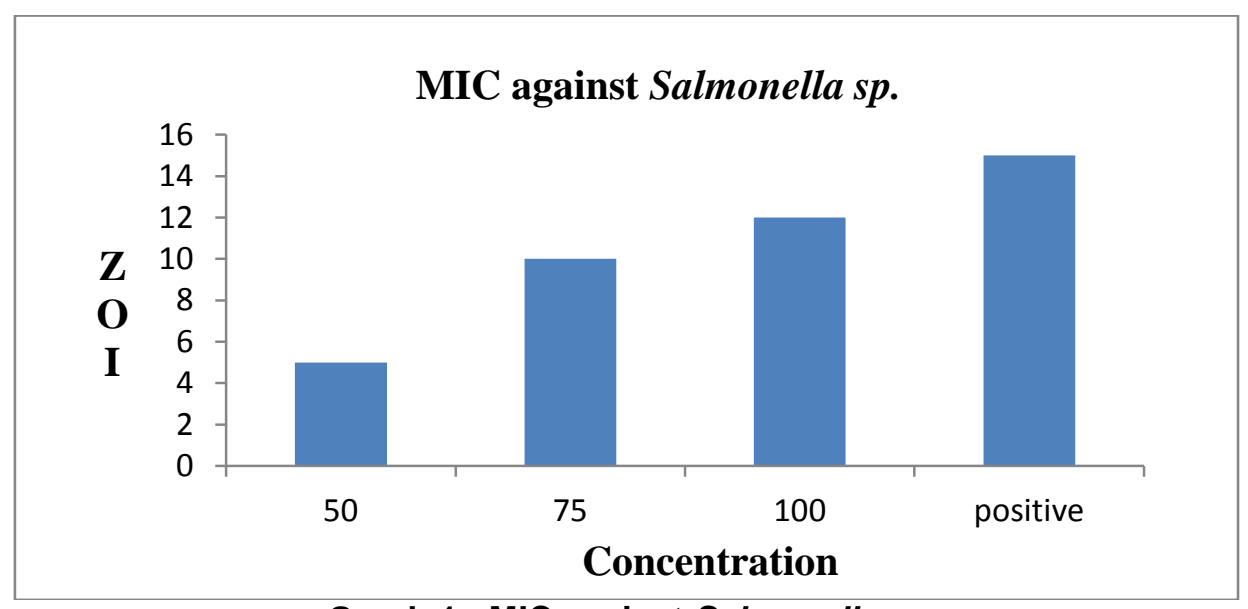

Graph 1: MIC against Salmonella sp

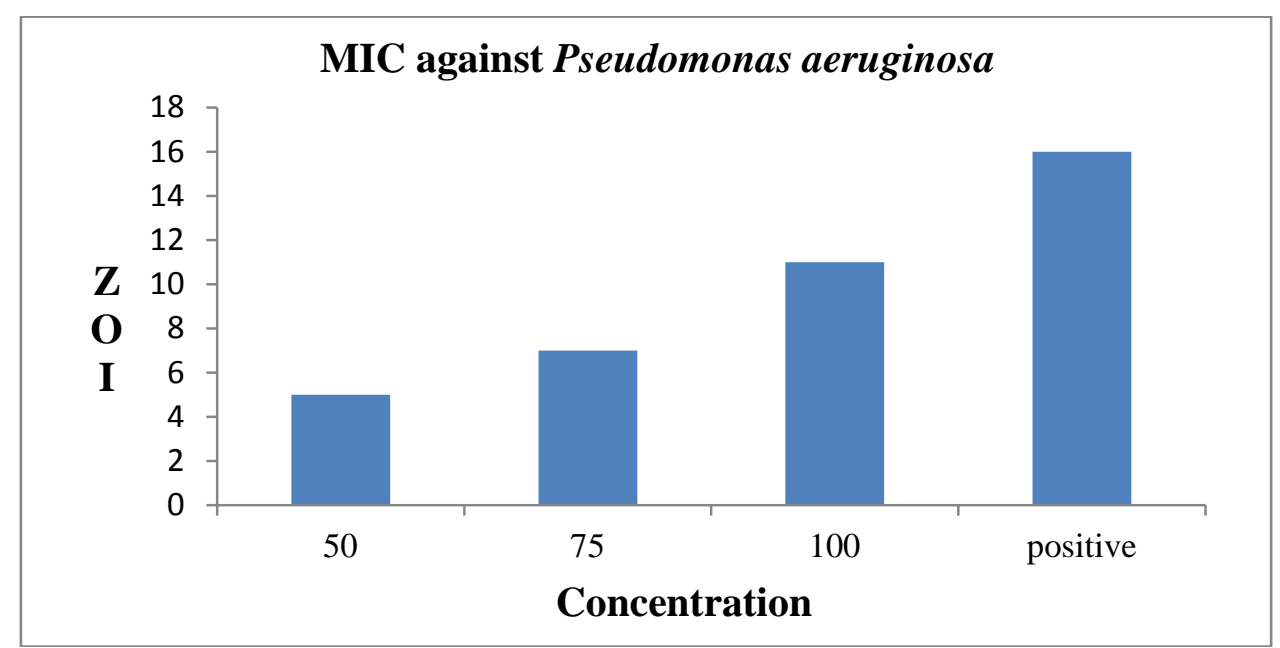

Graph 2: MIC against Pseudomonas aeruginosa

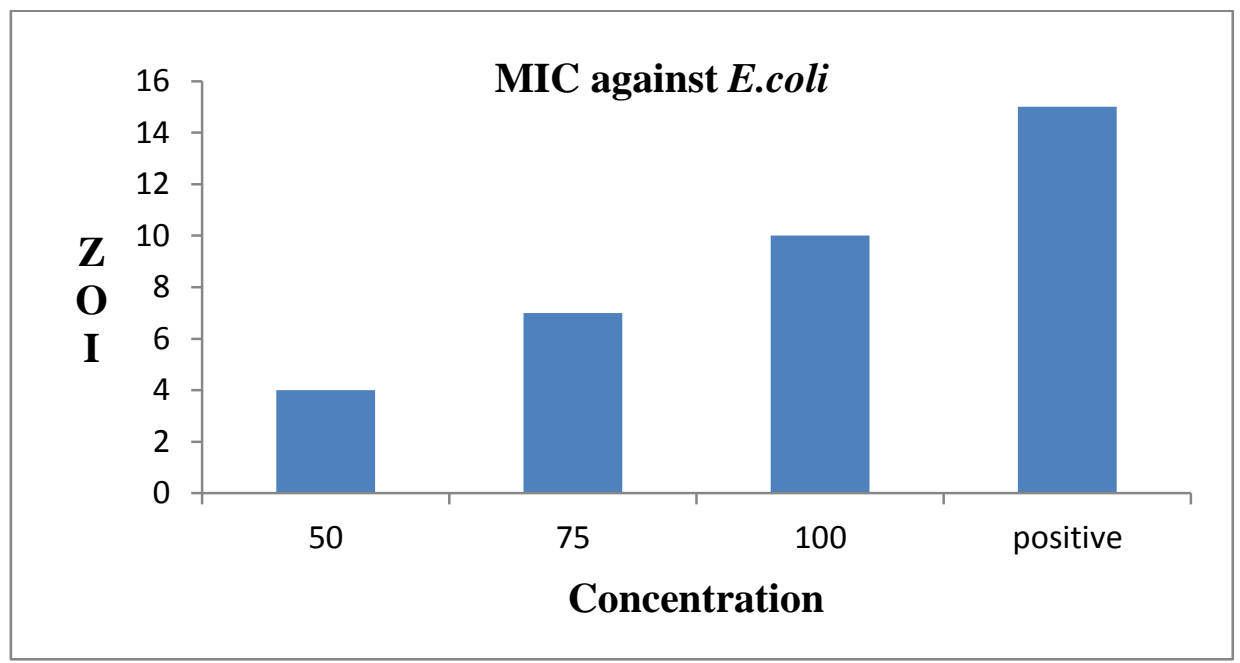

Graph 3: MIC against E.Coli 


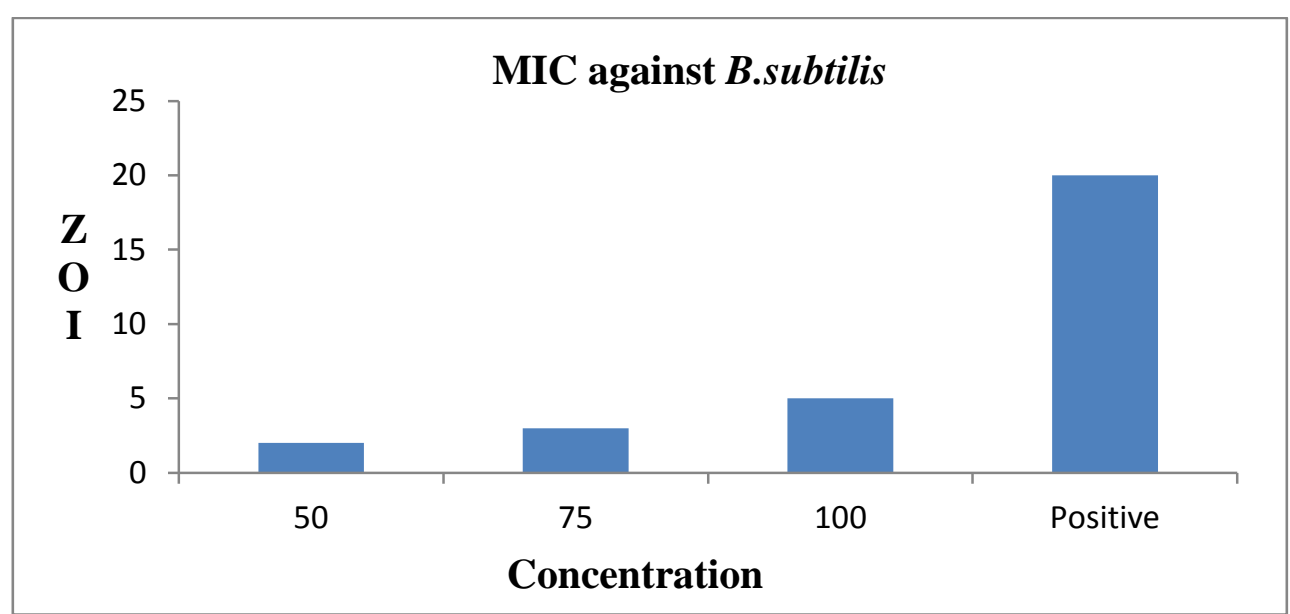

Graph 4: MIC against B.subtilis

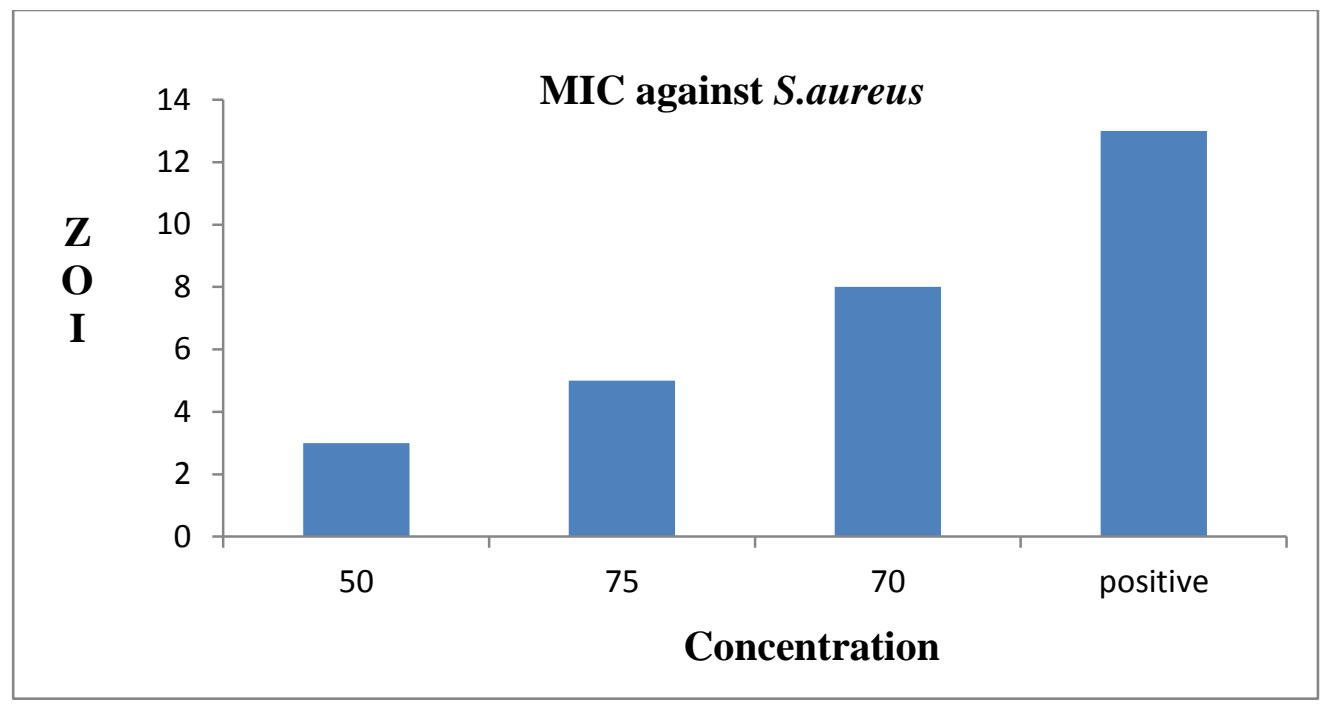

Graph 5:MIC against S.aureus

Table 1: Result of Phytochemical Tests

\begin{tabular}{|c|c|c|c|}
\hline Tests & Extracts of Tamarind fruit & Extracts of Bay leaves & Extracts of Mustard leaves \\
\hline Alkaloids & Positive & Positive & Positive \\
\hline Saponin & Positive & Positive & Positive \\
\hline Tannin & Positive & Positive & Positive \\
\hline Flavonoid & Positive & Positive & Positive \\
\hline Starch & Negative & Negative & Positive \\
\hline Carohydrate & Negative & Positive \\
\hline Protein & Positive & Negative & Negative \\
\hline Fat & Positive & Positive & Positive \\
\hline
\end{tabular}


Table 2: Result of Antibacterial Tests

\begin{tabular}{|c|c|c|}
\hline Sample & Organisms & ZOI (in mm) \\
\hline \multirow{4}{*}{$\begin{array}{l}\text { Positive control } \\
\text { (Ciprofloxacin) }\end{array}$} & S. aureus & 13 \\
\hline & E. coli & 10 \\
\hline & B. subtilis & 7 \\
\hline & Palm bacteria & 22 \\
\hline \multirow{4}{*}{ Tamarind } & S. aureus & 15 \\
\hline & E. coli & 12 \\
\hline & B. subtilis & 09 \\
\hline & Palm bacteria & 15 \\
\hline \multirow{4}{*}{ Mustard } & S. aureus & 12 \\
\hline & E. coli & 09 \\
\hline & B. subtilis & 05 \\
\hline & Palm bacteria & 12 \\
\hline \multirow{4}{*}{ Bay Leaf } & S. aureus & 2 \\
\hline & E. coli & 2 \\
\hline & B. subtilis & 12 \\
\hline & Palm bacteria & 10 \\
\hline
\end{tabular}

Table 3: Result of Chromatography

\begin{tabular}{|c|c|c|c|}
\hline Samples & Solute & Solvent & Retention Factor \\
\hline Leaves of Bay & 2.8 & 4.8 & 0.5 \\
\hline Leaves of Mustard & 2.5 & 5.8 & 0.4 \\
\hline Fruit of Tamarind & 2.8 & 4.8 & 0.5 \\
\hline
\end{tabular}

Table 4: Formulation of hand sanitizer

\begin{tabular}{|c|c|}
\hline Excipients & Quantity(in gm) \\
\hline Extracts of Leaves of Mustard & 1.5 \\
\hline Extracts of Leaves of Bay & 1.5 \\
\hline Extracts of Fruit of Tamarind & 1.5 \\
\hline Camphor & 1.5 \\
\hline Glycerin & 0.75 \\
\hline Water & $3 \mathrm{ml}$ \\
\hline Alcohol & $6 \mathrm{ml}$ \\
\hline Polysorbate & 0.15 \\
\hline SLS (Sodium lauryl sulphate) & 0.15 \\
\hline
\end{tabular}


Table 5: Evaluation

\begin{tabular}{|c|c|}
\hline Chemical/Physical parameter & Result \\
\hline pH & 4 \\
\hline Colour & Light brown \\
\hline Odour & Aromatic \\
\hline Texture & Fine \\
\hline Appearance & Translucent \\
\hline
\end{tabular}

Table 6: MIC against Palm bacteria, $S$ aureus, B. Subtilis and E. coli

\begin{tabular}{|c|c|c|c|c|}
\hline \multirow{2}{*}{ Concentration } & \multicolumn{4}{|c|}{ Zone of Inhibition(in mm) } \\
\hline & Palm Bacteria & S. aureus & B. subtilis & E. coli \\
\hline $\begin{array}{c}\text { Positive Control } \\
\text { (Ciprofloxacin) }(10 \mu \mathrm{l})\end{array}$ & $10 \mathrm{~mm}$ & $20 \mathrm{~mm}$ & $15 \mathrm{~mm}$ & $12 \mathrm{~mm}$ \\
\hline $\begin{array}{l}\text { Formulated Hand } \\
\text { Sanitizer }(100 \mu \mathrm{l}) \\
\text { (Undiluted) }\end{array}$ & $9 \mathrm{~mm}$ & $4 \mathrm{~mm}$ & $8 \mathrm{~mm}$ & $5 \mathrm{~mm}$ \\
\hline $\begin{array}{c}\text { Formulated Hand } \\
\text { Sanitizer }(100 \mu \mathrm{l})(1: 2)\end{array}$ & $8 \mathrm{~mm}$ & $0.5 \mathrm{~mm}$ & $2 \mathrm{~mm}$ & $3 \mathrm{~mm}$ \\
\hline $\begin{array}{c}\text { Formulated Hand } \\
\text { Sanitizer }(100 \mu \mathrm{l})(1: 4)\end{array}$ & $5 \mathrm{~mm}$ & $0 \mathrm{~mm}$ & $0 \mathrm{~mm}$ & $2 \mathrm{~mm}$ \\
\hline $\begin{array}{c}\text { Formulated Hand } \\
\text { Sanitizer }(100 \mu \mathrm{l})(1: 8)\end{array}$ & $0 \mathrm{~mm}$ & - & - & $0 \mathrm{~mm}$ \\
\hline
\end{tabular}

Table 7: Comparison of Different Hand Sanitizer

\begin{tabular}{|c|c|c|}
\hline Sample & Volume $(\boldsymbol{\mu l})$ & ZOI $(\mathbf{m m})$ \\
\hline Dettol & 100 & 2 \\
\hline Lifebuoy & 100 & 4 \\
\hline Himalaya & 100 & 5 \\
\hline Herbal & 100 & 15 \\
\hline
\end{tabular}




\section{REFERENCES}

1. Guarise M, Borgonovo G, Bassoli A and Ferrante A. Evaluation of Two Wild Populations of Hedge Mustard (Sisymbrium officinale (L.) Scop.) as a Potential Leafy Vegetable. Horticulturae. 2019;5:13.

2. Carnat A, Fraisse D, Carnat AP, Groubert A and Lamaison JL. Normalization of hedge mustard, Sisymbrium officinale L. Annales Pharmaceutiques Françaises. 1998;56: 36-39.

3. Calcinoni $O$ Sisymbrium. Singers' Plant Efficacy in Reducing Perceived Vocal Tract Disability. Journal of Otolaryngology-ENT Research. 2017;8(2):00243.
4. Kaushik A, Chauhan V and Dr Sudha. Formulation And Evaluation Of Herbal Cough Syrup. European Journal of Pharmaceutical And Medical Research. 2016;3(5):517-522.

5. Michael M. Herbal Formulas For Clinic and Home. Bisbee, AZ 85603. 1995;134.

6. Choudhary N and Sekhon BS. An overview of advances in the standardization of herbal drugs. J Pharm Educ Res. 2011;2(2):55-70.

7. Goswami PK and Srivastava RS. Development and evaluation of herbal syrup from root extract of nothosaerva brachiata and gomphrena celosiodies. International journal of research in pharmacy and chemistry. 2016;6(3):473-475. 